\title{
The largest magmitudes of earthquakes associated with some historical vollcamic eruptions and their volcanological significance
}

\author{
Izumi Yokoyama \\ Higashi 1-17-7-1304, Kunitachi, Tokyo, Japan
}

\begin{abstract}
We know several reports of earthquake swarms associated with volcanic eruptions in the 19th century or older periods when seismographs were not yet available. Even if we have no seismographs, the largest magnitudes of earthquakes can be estimated by the maximum distances of perceptibility which are determined by reports of felt shocks or by records of earthquake movements at various distances from the origins. For example, the largest magnitudes of the earthquake swarms associated with the 1815 eruption of Tambora is estimated at 7 by the reports of felt shocks from three sites and that of the 1883 eruption of Krakatau is estimated at 5 by examination of magnetograms in place of seismograms. The magnitude of the 7 class is exceptionally large as volcanic origin, but we know a few examples besides Tambora. The magnitude 5 of the Krakatau eruption is rather small contrary to our expectation, and implies that crustal stresses had not accumulated much at the Krakatau area to cause larger earthquakes. The earthquake magnitudes associated with volcanic eruptions are not necessarily proportional to explosion magnitudes or volume of volcanic ejecta, and may have a volcanological significance. Such volcanic earthquakes may be closely related to readjustments of tectonic stresses caused by magma movements or phase transitions of magmatic material beneath and around volcanoes, and may be called magmatotectonic earthquakes.
\end{abstract}

Key words earthquake magnitudes - distances of perceptibility - 1815 eruption of Tambora $18 \$ 3$ eruption of Krakatau - magmatotectonic earthquakes

\section{Introduction}

Earthquake magnitude is one of the important parameters to discuss tectonic significance of an earthquake. This also applies to volcanic earthquakes. The magnitudes are usually determined by epicentral distances, amplitudes or duration periods of seismic waves recorded with seismographs.

Mailing address: Dr. Izumi Yokoyama, Higashi 1-177-1304, Kunitachi, Tokyo 186-0002, Japan; e-mail: iyokoya@aol.com
We know many important volcanic eruptions in our history which may have been accompanied by major earthquakes. It is desirable to know the magnitudes of such volcanic earthquakes to grasp the whole aspect of the eruptions. The 1815 eruption of Tambora and the 1883 eruption of Krakatau both in Indonesia were outstandingly large eruptions. In the 19th century, seismographs were not yet used in practice. In the following, the magnitudes of the earthquakes associated with the above eruptions shall be determined by their maximum distances of perceptibility which shall be estimated by methods other than seismometry. In addition, we may confirm the magnitudes of the earthquakes by examination of damage at known epicentral distances. A variety of magnitudes of volcanic earthquakes inspires us to discuss their volcanological significance. 


\section{Relation between maximum distance of perceptibility and magnitude}

Earthquake magnitude can be empirically determined using maximum distance of perceptibility $R(\mathrm{~km})$. Some formulas have been proposed as follows:

Gutenberg and Richter (1956)

$$
M_{L}=-3.0+3.8 \log R
$$

for Southern California;

Ichikawa (1960)

$$
M_{J}=-1.0+2.7 \log R
$$

for Japan;

Utsu (1961)

$$
\begin{gathered}
\log R= \\
=-1.03+1.0 M_{J}-0.082 M_{j}^{2}+0.0024 M_{J}^{3}
\end{gathered}
$$

for Japan, land area;

where $M_{L}$ denotes local magnitude and $M_{J}$ is the JMA (Japan Meteorological Agency) magnitude which is mostly based on $M_{s}$ (surface wave magnitude). The three formulas are tabulated by Utsu (1999) as shown in table I which is somewhat dispersed for larger magnitudes. In addition, the magnitudes determined in such a way depend strongly on local differences in attenuation of seismic waves, and are inevitably somewhat erroneous. To determine earthquake perceptibility during volcanic eruptions of old times, we should discriminate true earthquake movements from air vibrations caused by explosions. In the following, two examples of magnitude determination shall be discussed.

\section{The largest magnitude of the earthquakes associated with the 1815 eruption of Tambora, Sumbawa}

This eruption is believed to be the largest event in history from the viewpoints of volume and dispersion of the pyroclastic ejecta, explosion sounds and optical after effects on the atmosphere. The 1815 activity of Tambora actually started on April 5 and reached its paroxysm on April 10, and there were no particular reports on earthquakes during the period. Therefore, the largest earthquake associated with the eruption may possibly have occurred during the paroxysm of April 10.

Stothers (1984) states the chronology of the day of eruption as follows: «At about 7 p.m. on April 10 (local time), the eruption intensified and attained its paroxysm. As viewed from Sanggar (about $30 \mathrm{~km}$ to the east), three columns of 'flame' rose up from the crater. Between 10 and 11 p.m., violent winds blew at Sanggar incessantly. Possibly the caldera formed by collapse at shortly before 10 p.m. Very loud explosions were heard all night throughout Java as far as Cirebon (1050 $\mathrm{km}$ west). In many places the sound waves produced concussions that resembled mild earthquakes (perhaps some were true earthquakes)». In this report, we cannot specify the places and the perceptibility of the earthquakes there.

According to Petroeschevsky (1949), at $19 \mathrm{~h}$ on April 10, explosions were heard at Banka $(1500 \mathrm{~km})$ and Benkoelan on Sumatra (1775 $\mathrm{km}$ ) while earthquakes were felt as far as Surabaya on Java $(600 \mathrm{~km})$, Madura Island $(500$ $\mathrm{km})$, and Banjuwangi on east Java $(400 \mathrm{~km})$. Considering this statement, we may assume that the largest earthquake occurred in association with these explosions, and the maximum distance of perceptibility roughly as $500 \mathrm{~km}$.

Table I. Relation between magnitudes and maximum distances of perceptibility after Utsu (1999).

\begin{tabular}{ccccccccccl}
\hline \hline$M$ & 3.5 & 4.0 & 4.5 & 5.0 & 5.5 & 6.0 & 6.5 & 7.0 & 7.5 & \\
\hline & 51 & 70 & 94 & 127 & 172 & 234 & 316 & 428 & 580 & $:$ G-R \\
$R$ & 46 & 71 & 109 & 167 & 256 & 391 & 599 & 918 & 1407 & $:$ Ichikawa \\
$(\mathrm{km})$ & 37 & 65 & 107 & 166 & 245 & 344 & 462 & 596 & 741 & $:$ Utsu \\
\hline
\end{tabular}


Then, from table I, we obtain the largest magnitude of the Tambora earthquakes as approx. 7.

\section{The largest magnitude of earthquakes associated with the 1883 eruption of Krakatau, Sunda}

This eruption was also one of the largest eruptions in historical times, and we have many more data than the 1815 eruption of Tambora. However, the earthquakes associated with this eruption have not been quantitatively discussed.

Verbeek (1888) referred the earthquakes of 1883 in the region of the Sunda Straits, and mentioned several shocks felt in May. After May 20, Krakatau volcano in the strait began to issue steam and ashes with booming sounds. The continued moderate eruptions had been growing in intensity. In August the following earthquakes were felt: at $19 \mathrm{~h} 50 \mathrm{~min}$, August 26 (local time), heavy earth shocks were felt at Java's First Point $(78 \mathrm{~km})$. At $02 \mathrm{~h} 30 \mathrm{~min}$ and $03 \mathrm{~h} 00 \mathrm{~min}$, August 27, some rumbling shocks (?) were felt at Anjer $(55 \mathrm{~km})$. There are no reports of shocks commonly felt at both the towns. These most likely were the result of vibrations in the air. Actually the volcano had repeated eruptions since midnight $(00 \mathrm{~h})$ of August 27 and their air waves were recorded by a gas pressure meter at Batavia.

Verbeek concluded that the reports on the earth shocks of August 27 during the big eruption were very unreliable. The present author suspects that the largest earthquake of the 1883 eruption possibly may have been confused with air waves during gigantic eruptions on August 27, probably simultaneously with the largest paroxysm. In this respect, we should pick up true earthquake motions from chaotic ground movements observed around the volcano.

Around 1883, seismographs were under development in the world. For an example, in Japan, a set of routine seismographs of Palmieri type using U-tubes of glass containing mercury was being replaced by that of Ewing-Gray-Milne type using a pendulum. Thus we know that there were no seismographs which could detect earthquakes associated with the 1883 Krakatau eruptions.

As a substitute for a seismograph, we find the magnetograms of the three components recorded during the catastrophic eruptions at Batavia in fig. 8 in the book «Krakatau» by Verbeek (1888) which are reproduced in fig. 1. They can also be found in the book «Krakatau 1883» by Simkin and Fiske (1983).

The geomagnetic observations at Batavia $\left(6^{\circ} 11.0^{\prime} \mathrm{S}, 106^{\circ} 48.5^{\prime} \mathrm{E}\right)$ were commenced in 1866 and were equipped with Adie's magnetograph that was composed of three variometers. Its details and dimensions are not well known at present .

Verbeek (1888) attributed the magnetic disturbances shown in fig. 1 to the magnetic iron contained in the ash because there were ashfalls during that time, and presumed the eruption itself not to influence the magnetic variations. The present author suspects that they were mainly due to mechanical disturbances superimposed on the daily magnetic variations because the magnetographs were unintentionally protected against ashfalls by a housing for optical recordings.

To detect earth movements at Batavia, we will utilize the oscillating systems of the magnetographs as seismographs. For the purpose, the oscillating characteristics of the magnetographs shall be examined in the following. The declination variometer $(D)$ was a small magnet with a mirror, suspended by a thin thread of cocoon, and has a proper period of approx. $1 \mathrm{~s}$ as mechanical pendulums if we assume the length of the suspending threads to be $0.3 \mathrm{~m}$, and hence may be rather sensitive to low-frequency motions. The horizontal force variometer $(H)$ was a small magnet with a mirror, suspended by two thin metal threads (bifilar) and twisted perpendicularly to the magnetic meridian, and has a shorter period of bifilar suspension, and hence may be sensitive to rather highfrequency motions but unstable to strong movements. The vertical force variometer $(Z)$ was a plate magnet with a mirror, horizontally pivoted near the center of gravity on a knife-edge (balance type), and has a longer period that depends on the distance between the mass-center and the 

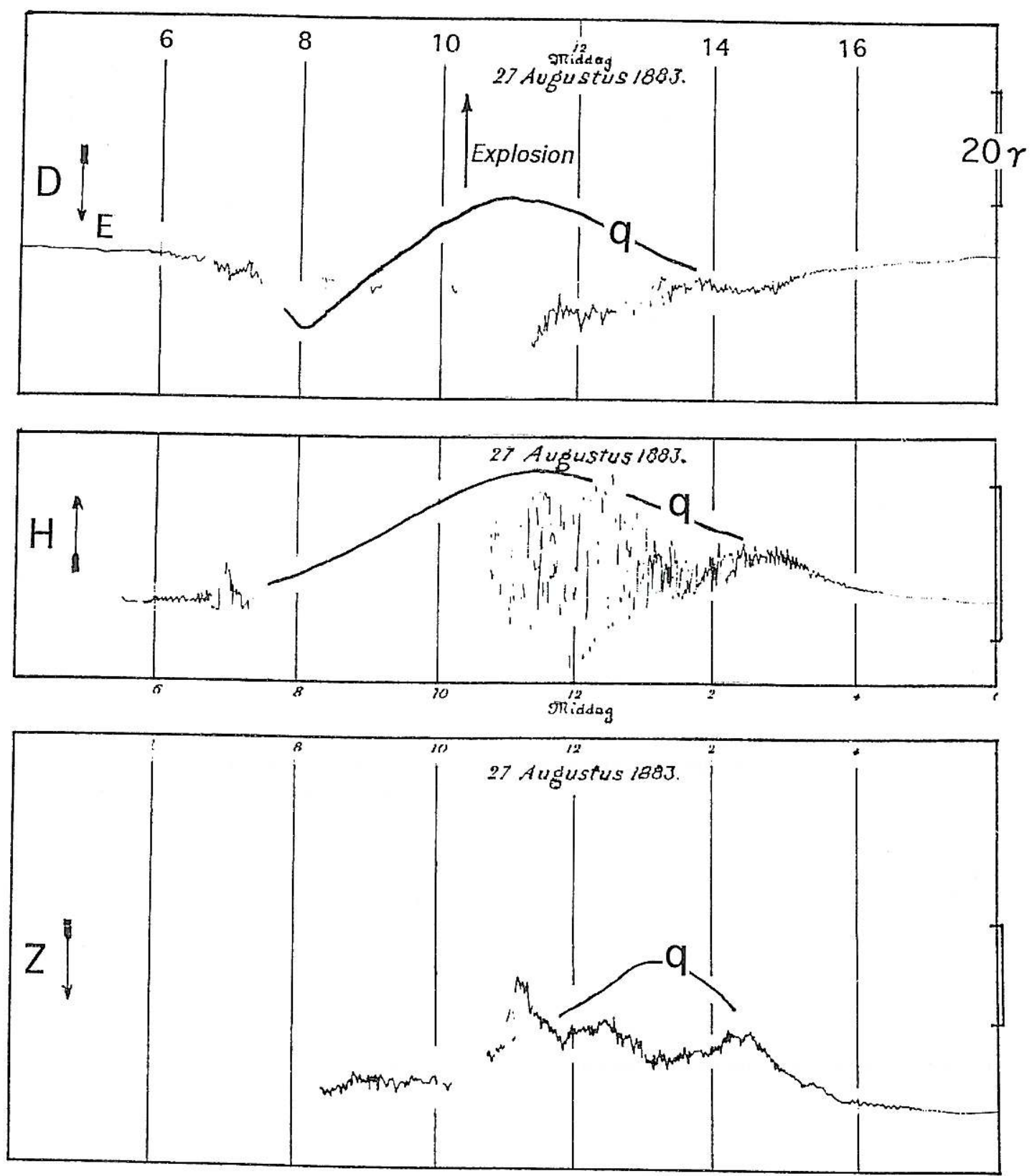

Fig. 1. Magnetogram of 27 August 1883 recorded at Batavia reproduced from Verbeek (1888). The q-curves are added by the present author and indicate the daily variations on quiet days. 
knife-edge, and hence is most dull to high frequency motions, but its movements are sometimes irregular due to friction of the knifeedge.

The movements of the three magnets were optically recorded in a dark room, and blurs of the traces in fig. 1 resulted from rapid oscillations of the optical images. The magnets were affected by geomagnetic and mechanical disturbances due to earthquake motions. Because the observation room was shielded from the open air, air waves may have been mostly protected, but infrasonic waves from the explosions might have given rise to ground motions during their propagation. In the figure, the smooth curves labeled with «q" show the daily geomagnetic variations on quiet days deduced from fig. 18 in the book of Chapman and Bartels (1940). We may say that the $H$ and $D$ variometers registered the ground motions well, and the $Z$ variometer clearly recorded the main motions of earthquake waves but its movements may have suffered from some irregularity due to friction of the knife-edge, after the major disturbances. In any case, the three magnetometers showed small disturbances caused by explosions in the early morning, and the largest deviations by the paroxysmal explosion around $10 \mathrm{~h} 05 \mathrm{~min}$. It is probable that the largest earthquake occurred simultaneously with the destructive paroxysms.

The largest earthquake related to the eruption on August 27 was large enough to disturb the $D$ variometer, but not enough to upset the $H$ variometer, and to cause remarkable movements of the $Z$ variometer. The three magnetometers responded to the earthquake motions, but remained stable. Hence we may assume that the largest earthquake associated with the Krakatau eruption was just perceptible at Batavia ( $\Delta=160 \mathrm{~km}$ ). When we adopt $R$ as $160 \mathrm{~km}$, $M$ is estimated at 5 in table I.

In Verbeek's Album (1888) and also in the book by Simkin and Fiske (1983), we find the sketches of two lighthouses along the Sunda Straits that survived the 1883 eruption of Krakatau: one is at Vlakke Hoek, Sumatra about $105 \mathrm{~km}$ away from the volcano, a 60-m-high iron structure built in 1880 . This was washed by tsunamis, and resisted against earthquakes dur- ing the eruptions. The other is at Java's First Point about $78 \mathrm{~km}$ from the volcano, about $50 \mathrm{~m}$ high, built with stone on a 40 -m-high rock. This had been higher before, but was severely damaged by the earthquake of September, 1880 and its top part was demolished. However, it was not damaged by tsunami and earthquakes during the 1883 eruptions.

Modified Mercalli's seismic intensity (MM) I has been empirically related to epicentral distance $\Delta$ (in $\mathrm{km}$ ) and earthquake magnitude $M$ by several researchers. One example proposed for California by Esteva and Rosenblueth (1964) is

$$
I=8.16+1.45 M-2.46 \ln \Delta .
$$

By this relation, seismic intensities to be caused by earthquakes of the $M 5$ class at epicentral distance $\Delta=105$ and $78 \mathrm{~km}$ are calculated as 4.0 and 4.7 in MM scale, respectively. These intensities agree with the fact that even the stone lighthouse at the nearer site was not damaged by the earthquake. By the relationship (4.1), earthquakes of $M 6$ class should cause seismic intensities of 5.4 and 6.1 at the above distances respectively, and the nearer (stone) lighthouse probably may have been damaged. If the magnitude were $7, \mathrm{MM}$ seismic intensities at both the sites should have been 6.9 and 7.6, respectively, and the farther lighthouse must surely have been damaged while the nearer one surely destroyed. Hence, we may say that the largest magnitude of the 1883 Krakatau earthquakes should have been around 5 .

Considering the violent explosions and the large amount of pyroclastic ejecta of $12 \mathrm{~km}^{3}$ in Dens Rock Equivalent (DRE) in the 1883 eruption of Krakatau, the earthquake magnitude 5 is unexpectedly small. It is probable that originally the crust around the volcano had not stored elastic energy enough to cause earthquakes of larger magnitudes than 5 . Such magnitudes of volcanic earthquakes are another indicator of magnitude of volcanic eruptions than VEI (Volcanic Explosivity Index) devised by Newhall and Self (1982) that depends mainly on the volume of tephra and cloud column height. 


\section{Some examples of earthquakes of magnitude 7 class associated with volcanic eruptions}

Exceptionally large earthquakes of $M 7$ have occurred during some large historical eruptions. Besides the 1815 eruption of Tambora, we know of the 1912 eruption of Katmai, the 1914 eruption of Sakurajima, and the 1996 eruption of Karymsky. As an exception, the 1975 Hawaii earthquake was volcanic but not accompanied by large eruptions. In the following, we examine some details of these earthquakes.

The 1815 eruption of Tambora, Sumbawa ( $M 7)$ - This was the greatest pyroclastic eruption in the historical periods. The products of the eruption were trachyandesite, and amounted to $50 \mathrm{~km}^{3}$ in DRE. The largest earthquake of $M 7$ may have occurred simultaneously with the paroxysms on April 10. After the eruption, there remained a caldera measuring approx. $6 \mathrm{~km}$ in diameter on the summit. The base of this volcano measures $40-50 \mathrm{~km}$ in diameter.

The earthquake of $M 7$ may have caused crustal deformations over a wide area though no geodetic deformations on and around the volcano were reported.

The 1912 eruption of Katmai, Alaska (M, 7.0) - The eruption occurred in the early 20 th century, and at a remote place in that time. The eruption produced ignimbrite of $11 \mathrm{~km}^{3}$ and plinian fall deposits of $17 \mathrm{~km}^{3}$ from the Novarupta crater; their DRE volume amounts to $13 \mathrm{~km}^{3}$ in total. Many earthquakes associated with the eruptions were recorded by distant seismological stations. According to Abe (1992), of 50 earthquakes detected, 14 have $M_{\mathrm{S}}=6.0$ and greater, and the largest one of $M_{S} 7.0$ took place on June 7 during a violent phase of eruptions, continuing from June 6 to 8 , simultaneously with a large explosion. Its epicenter was located near Novarupta.

A large amount of andesite-rhyolite magma erupted from the Novarupta crater, and at Mt. Katmai, $10 \mathrm{~km}$ east of Novarupta, a 600-m-deep and 3-km-across caldera collapsed, and detailed explanation of the processes are not established. Such large earthquakes may have released the crustal stress accumulated by magma movements beneath the volcano. We have no reports of crustal deformations corresponding to $M 7$ around Katmai or Novarupta.

The 1914 eruption of Sakurajima, Japan $\left(M_{s} 7.1\right)$ - An earthquake of $M 7.1$ occurred half a day after the outburst of parasitic craters and one day before the commencement of lava outflows. Its epicenter was located at about $9 \mathrm{~km}$ southwest of the volcano not directly near the volcano and the focal depth was determined at roughly $10 \mathrm{~km}$ (Abe, 1981). This eruption was a kind of fissure eruption from craterlets on both the eastern and western slopes of the volcano, and large craters were not formed. The effused andesitic magma amounted to $1.4 \mathrm{~km}^{3}$ DRE. The eruption caused subsidence of the surrounding area extending to a distance of $50 \mathrm{~km}$ from the volcano and amounting to approx. $150 \mathrm{~cm}$ at the maximum near the volcano. Such deformation may be related to the large earthquake of $M 7$. It is noticeable that similar deformations may have been repeatedly accompanied by eruptions in the past (Yokoyama, 1986).

The 1996 eruption of Karymsky, Kanchatka ( $M$ 6.9) - The eruption occurred at Karymsky volcano and migrated southwards to Lake Akademia Nauk, both are within the Karymsky volcanic center. According to Fedotov (1998), an earthquake of $M 6.9$ occurred after earthquake swarms, and was located at the southernmost part of the center. A major long-lived summit eruption of Karymsky volcano followed this large earthquake by $5 \mathrm{~h}$, and a few weeks later, andesite-dacite lavas began to flow out from the new crater. All the ejecta amounted to approx. $3 \times 10^{7}$ tons. Levina and Maguskin (2000) reported that seismic active volume or seismic focal volume was expressed as $30 \times 15 \times 20=$ $9000 \mathrm{~km}^{3}$ and was located at $10-15 \mathrm{~km}$ north of the volcano. Gordeev et al. (1998) explain that this earthquake was a crustal tectonic and reactivated a fault, through which magma began to rise. However, it is also probable that the earthquake was closely associated with magma movements in the depths. Maguskin et al. (1998) carried out geodetic surveys in the volcano center, and found the deformations extending from 
Akademia Nauk to Dvor calderas, for approx. $18 \mathrm{~km}$. The earthquake of $M 6.9$ may have been related to crustal activity over the whole Karymsky volcanic center extending approx. $33 \mathrm{~km}$ in the north-south direction.

The 1975 Kalapana earthquake, Hawaii $\left(M_{s} 7.2\right)$ - The Hawaii volcanoes afford us an exceptional example of a large earthquake of magnitude 7 class that was of volcanic origin but unaccompanied by large eruptions. The Kalapana earthquake on November 29, 1975 has been investigated from various standpoints. It caused a tsunami at the southern coast of Hawaii, and the coastal subsidence reached $2 \mathrm{~m}$ at the maximum. Ando (1979) interpreted that it was caused by forceful injection of magma into rift zones. But it was not directly related to the eruptions of Kilauea: according to Klein et al. (1987), a small summit eruption was triggered by the earthquake, but no east rift zone eruption occurred and its magma remained below the surface. This earthquake is a tectonic one originated from magma intrusions. Ando (1979) mentions that it may be a 100-year recurrence of a similar event in 1868 .

\section{Volcanological significance of earthquakes of magnitude 7}

\subsection{Magnitudes and deformation area}

As for the relation between magnitudes of tectonic earthquakes and the deformed area, Dambara (1966) found an empirical formula as

$$
1.53 M+9.08=\log D^{3}
$$

where $D$ is diameter of the crustal surface deformed by an earthquake and measured in centimetres. Dambara (1966) examined 19 tectonic earthquakes which occurred in Japan for the period from 1891 to 1964 and estimated $D$ from vertical deformations. Okada (1983) verified that volcanic earthquakes of $M$ 4-6 roughly satisfy this relation. By this formula, we obtain $D$ for $M 7$ and $M 5$ earthquakes as approx. 40 and $4 \mathrm{~km}$, respectively.

The 1883 eruption of Krakatau was accompanied by $M 5$ earthquakes and resulted in a depression measuring approx. $5 \mathrm{~km}$ in diameter. Of the four major eruptions, i.e. Tambora, Katmai, Sakurajima, and Karymsky, only the Sakurajima eruption is known to have been accompanied by remarkable deformation proportionate to $M 7$, and the Karymsky eruption had seismic active volume also proportionate to $M 7$. For the other two, Tambora and Katmai, we have no data of crustal deformation or seismic volume. As for the 1975 Kalapana earthquake $\left(M_{s} 7.2\right)$, the aftershock zone covered nearly an area of about $40 \mathrm{~km}$ long by $8 \mathrm{~km}$ wide (Thurber and Gripp, 1988), and Ando (1979) determined the source parameters, such as fault length $40 \mathrm{~km}$ and width $20-30 \mathrm{~km}$.

\subsection{Magnitudes of volcanic earthquakes}

Earthquakes of magnitude 7 are exceptionally large like volcanic ones. Our experience shows that magnitudes of earthquakes associated with major volcanic eruptions (volcanotectonic or A-type earthquakes) are usually limited to $M 5$ or so. As typical examples of major eruptions, we may mention the 1956 eruption of Bezymianny with $M 4.9$, the 1980 eruption of Mount St. Helens with $M 5.1$ and the 1991 eruption of Pinatubo with $M$ 5.7. Although these eruptions were very violent by various standards, their volcano volumes could not store seismic energy more than $M 5$, and burst into the eruptions causing sector collapses or caldera formations. The 1883 eruption of Krakatau is a case in point.

Earthquakes of $M 6$ class rarely occur around volcanoes during or after their eruptions, for example, $M 5.9$ after the 1962 eruption and $M 6.2$ after the 1983 eruption of Miyakejima, Japan, $M 6.0$ after the 1986 eruption of IzuOosima, Japan. These earthquakes took place in areas adjacent to the volcanoes, and may have occurred to readjust stress distribution in the crust produced by the eruptions.

As for volcanic earthquakes, the author suspects that there should be a distinction between large magnitudes of 7 and smaller magnitudes around 5 . Their difference in energy releases is about 1000 times and their mechanisms should differ from each other. If we adopt the relation 
between magnitudes and deformation areas expressed by eq. (6.1), the $M 5$ class originates from stress accumulation in local parts of volcanoes while the $M 7$ class originates from stress changes in regional area including volcanoes. At present, we may refer only five examples of volcanic earthquakes of the $M 7$ class as mentioned above. The Tambora and the Katmai earthquakes occurred simultaneously with their largest explosions while the other two occurred during eruptive phases. DRE volumes of their ejecta range from 2 to $50 \mathrm{~km}^{3}$ : it means that the magnitudes of the earthquakes associated with volcanic eruptions do not depend on the volume of their ejecta.

These earthquakes of the $M 7$ class may be closely related to stress accumulation caused by magma movements on a large scale, such as in the case of the 1975 Kalapana earthquake, and to readjustments of crustal stresses caused by large eruptions. Remarkable deformations accompanied by volcanic earthquakes may originate from phase changes of magmatic material as discussed by Matuzawa (1964). In such a sense, they may be called "magmatotectonic earthquakes».

\section{Concluding remarks}

The largest earthquake of the 1815 eruption of Tambora is estimated at $M 7$ as expected while that of the 1883 eruption of Krakatau at $M 5$ contrary to our expectations. The origin of the Krakatau eruption may have been limited to a local zone in spite of a large volume of the ejecta and high explosive pressure. Volcanic earthquakes of $M 7$ class are usually associated with large eruptions but the converse is not always true. And they are independent of volumes of their volcanic ejecta. The largest earthquakes associated with volcanic eruptions may be possibly another measure to estimate eruption magnitude.

$M 7$ earthquakes are 1000 times larger than $M 5$ earthquakes in energy releases, but distinctions, if any, between them in origin mechanism or in relations with volcanic eruptions are not necessarily clear. Uniquely, the 1975 Kalapana (Hawaii) earthquake is interpreted to be caused by magma injections into rift zones, and this suggests that the other earthquakes should have their own characteristic origins. In future, we should search for more persuasive characteristics of these large earthquakes from the standpoints of volcanology and seismology. More definitive conclusions must await the outcome of such researches.

\section{Acknowledgements}

The author gratefully acknowledges support by Dr. I. Purwana of the Meteorological and Geophysical Agency, Indonesia and Dr. C. Meester of the Seismology Department of the Royal Netherlands Meteorological Institute of the Bilt, for information on the magnetic observations at Batavia in 1883. A copy of Petroeschevsky's paper was supplied to the author by Mr. Igan S. Sutawidjaja of the Volcanological Survey of Indonesia, whom the author would like to thank. The author wishes to express his heartfelt thanks to Prof. R. Scandone who takes an interest in this problem and kindly advised him in the course of the discussion.

\section{REFERENCES}

ABE, K. (1981): Hypocenter and magnitude of the 1914 Sakurajima earthquake, Geophys. Bull. Hokkaido Univ., 39, 57-62 (in Japanese with English abstract).

ABE, K. (1992): Seismicity of the caldera-making eruption of Mount Katmai, Alaska in 1912, Bull. Seismol. Soc. Am., 82, 175-191.

ANDo, M. (1979): The Hawaii earthquake of November 29, 1975: low dipangle faulting due to forceful injection of magma, J. Geophys. Res., 84, 7616-7626.

CHAPMAN, S. and J. BARTELS (1940): Geomagnetism (The Clarendon Press, Oxford), vol. 1, pp. 542.

DAMBARA, T. (1966): Vertical movements of earth's crust in relation to the Matsushiro earthquake, J. Geod. Soc: Jpn., 12, 18-45 (in Japanese with English abstract).

Esteva, L. and E. Rosenblueth (1964): Espectros de temblores a distancias moderadas y grandes, Bol. Soc. Mex. Ing. Sismica, 2, 1-18.

FEDotov, S.A. (1998): Study and mechanism of the simultaneous 1996 Karymsky volcano and Akademii, Nauk caldera eruptions in Kamchatka, Volc. Seismol., 19, 525-566.

GordeEv, E.I., D.V. Droznin, M. Kasahara, V.I. LEVINA, V.L. LEONOV, H. MIYAMACHI, M. OKAYAMA, V.A. SALTYKOV, V.I. Sinitsyn and V.N. ChEbROV (1998): Seismic events associated with the 1996 
volcanic eruptions in the Karymsky volcanic center, Volc. Seismol., 19, 713-735.

GUTENBERG, B. and C.F. RiCHTER (1956): Earthquake magnitude, intensity, energy and acceleration. Second paper, Bull. Seismol. Soc. Am., 46, 105-145.

ICHIKAWA, M. (1960): On the relation between earthquake magnitude and maximum value of epicentral distance at limit of perceptibility, Q. J. Seismol., 25, 83-87 (in Japanese).

KLEIN, F.W., R.Y. KOYANAGI, J.S. NAKATA and W.R. TANIGAWA (1987): The seismicity of Kilauea's magma system. Volcanism in Hawaii, U.S. Geol. Surv., Prof. Pap., 1350, 1019-1120.

LEVINA, V.I. and M.A. MAGUSKIN (2000): Seismological and geodetic monitoring of Karymskii volcano, in Colima Volcano, Seventh International Meeting, abstracts, p. 91.

Mnciuskin, M.A., S.A. Fedotov, V.E. Levin and V.F. BAKHTIAROV (1998): Ground surface deformation caused by seismic and volcanic activity in the Karymsky volcanic center during January 1996, Volc. Seismol.. 19. 637-654.

MAtuZAWa, T. (1964): Study of Earthquakes, Uno Shoten. Tokyo, pp. 213.

Newhall, C.G. and S. SElF (1982): The volcanic explosivity index: an estimate of explosive magnitude for historical volcanism, J. Geophys. Res., 87, 12311238.

OKADA, H. (1983): Comparative study of earthquake swarms associated with major volcanic activities, in Arc
Volcanism, edited by D. SHIMOZURU and I. YOKOYAMA (Terrapub, Tokyo), 43-6I.

PETRoeschevsky, W.A. (1949): A contribution to the knowledge of the Gunung Tambora (Sumbawa), K. Ned Aardrijksk Genoosts Tijds, 66, 688-703.

SIMKIN, T. and R.S. FiSKE (1983): Krakatan 1883 - The Volcanic Eruption and its Effects (Smithsonian Institution Press, Washington, D.C.), pp. 464.

STOTHERS, R.B. (1984): The great Tambora eruption in 1815 and its aftermath, Science, 224, 1191-1198.

Thurber, C.H. and A.E. GripP (1988): Flexure and seismicity beneath the south flank of Kilauea volcano and tectonic implications, J. Geophys. Res., 93, 42714278 .

UTSU, T. (1961): A statistical study on the occurrence of attershocks, Geophys. Mag., 30, 521-605.

UTSU, T. (1999): Seismicity Studies: a Comprehensive Review (Univ. Tokyo Press), pp. 876 (table 3.9).

VERBEEK, R.D.M. (1888): Krakatau, Landsdrukkerij. Batavia, pp. 546.

YOKOYAMA, 1. (1981): A geophysical interpretation of the 1883 Krakatau eruption, J. Volcanol. Geotherm. Res., 9, 359-378.

YokoYAMA, I. (1986): Crustal deformation caused by the 1914 eruption of Sakurajima volcano, Japan and its secular changes, J. Volcanol. Geotherm. Res., 30, 283-302.

(received April 2, 2001: accepted May 31, 2001) 